\title{
Navigating Integration and Alienation in Migration: A Reading of Leila Aboulela's “The Museum" (1999)
}

\author{
Shaden Adel Nasser \\ Associate Professor of English Literature \\ Department of English Language \& Literature \\ Faculty of Women, Ain Shams University \\ shaden3900@gmail.com
}

DOI: $10.21608 / M I S J .2021 .72973 .1020$

Received: 18-4-2021

Accepted: 17-5-2021

Published: 20-5-2021

\begin{abstract}
When migrants move from their homeland to a new country, they carry their memories, beliefs, traditions, feelings of belonging with them. Arab Anglophone literature is a genre that deals with the distresses and difficulties of the Arab and African migrants, including cross-cultural conflicts and western perceptions and misconceptions of their identity, which lead to feelings of dislocation, alienation, and depression. The works of the Sudanese feminist and Scottish migrant, Leila Aboulela (1964- ), is part of the growing corpus of Anglophone Arab fiction. Most of her works explore the complex cultural perceptions between east and west in migration. In this discussion, the study elects to interrogate Aboulela's winning prize short story, "The Museum" (1999), where the Sudanese female protagonist, in Aberdeen, is torn between her expectations of integrating and improving her life and her feelings of isolation and strangeness in the host country. Thus, through a psychosocial analytic approach, the paper engages the concepts "identity", "acculturation", and "integration" to use these as tools to examine the east-west encounter in a migration experience. In so doing, the study elucidates the following issues: to what extent does Shadia, as a migrant, strive to adjust to the new culture in the receiving country? And how did the hostility and misconception of the west to her African identity negatively affect her psychological well-being?
\end{abstract}


Keywords: Identity, Leila Aboulela, integration, alienation, deculturation

\section{Introduction}

The migration researches have a long history in negotiating cross-cultural encounter and social psychology. The migration process can be better understood by three distinct stages: pre-migration, during migration, and postmigration. Generally speaking, migrants leave their homeland in search of better social and economic chances. However, in some cases, some migrants in the post-migration stage experience various anxieties during their attempts of adjustment to the culture of the new land due to several reasons. Two of the crucial reasons, according to C. C. Sangalang, D. Becerra, F. M. Mitchell, and I. Kim, are the "dissonance between one's culture of origin and the host culture (acculturative stress)... [and] experiences of racial/ethnic discrimination" (2019, p. 910). Thus, considering these intricacies and drawing on psychological studies on migration, the study focuses on the impact of the cultural clash and misleading image of the west to Africa on the psych of the Sudanese female migrant, in Leila Aboulela's "The Museum", in two main settings; the Aberdeen University and the African museum. Thus, the paper is organized as follows: The first part defines the acculturation process with a brief outline of the primary concepts that structure this study namely 'identity' and 'integration', which offer a framework to the analysis of the protagonist's migration experience. Consequently, the study answers the following: what did the protagonist, Shadia, as a migrant, attempt to integrate into the western society? And how did the hostility and misconception of the west to her African identity leads to psychological injuries?

\section{Conceptual Framework}

Identity is considered a keynote aspect in all migration studies. Conceptually, it is defined as a group of implications that help the individual to know who he/she is, and determine if he/she is an active member of a particular group, or endowed with specific features that identify him/her as a special person. 
Moreover, identity can be perceived as personal beliefs in relation to social groups, such as religious, or ethnic, or racial groups. In addition, Dominic Abrams and Michael A. Hogg, in "Social identifications: A social psychology of intergroup relations and group processes", perceive identity as a person's concept of who he/she is in the eyes of his fellow-men and in the eyes of the Other (2006, p. 2). Migration transcends identity substituting the sense of who the individual is with the sense of where he fits and what his/her future roles within the new society are. Thus, migrants' identities change according to new dynamic contexts in which new forms of cultural identities are produced. In the host country, migrants feel alienated and isolated when faced with the shocking reality of exclusion and rejection which differs from their impression of the receiving country as a place better than one's country of origin. Thus, by experiencing exclusion, migrants find themselves devoid of history or image and, consequently, try to search for social approval by a psychosocial process termed as acculturation process.

Acculturation process, according to J. W. Berry (2001), refers to change and adaptation. In "A psychology of immigration", Berry divides acculturation into four levels, namely, assimilation, integration, separation, and marginalization. Since our focus of interest is on integration, it is important to know what it means. For Berry, integration is defined as "maintaining one's original culture...while engaging into a positive communication with the receiving society" (2001, p. 619). He further adds that this strategy can encourage positive adaption of migrants if only the receiving culture endorses cultural diversity through openness and inclusion. In this sense, integration is known as "sociocultural integration", which refers to the individual's ability to successfully cope with daily events and demands in the new land. This process includes knowing a new culture/language and forming interpersonal relations to members of the new society, such as friendships, enterprises, and marriages. Acculturation, as a bridge between the migrant's culture of origin and the culture of the new society, can lead to emotional reaction referred to as "acculturative stress" (2001, p. 624) when he/she fails to achieve this strategy.

\section{Misriqiya}


Acculturative stress is usually associated with the migrant's negative integration, which includes stereotyping, discrimination, and rejection by the host society, leading, in a psychological level, to identity confusion, stress, depression, and culture shock experienced by some acculturating migrants. João Sardinha, in "Immigrant Associations, Integration and Identity", holds that discrimination and rejection are central barriers that exacerbate psychological dysfunctions among the migrants including, feelings of isolation and marginalization. Such barriers are best described by Sardinha (2009) as,

institutional, coming in the form of unequal citizenship rights, ...or structural barriers in different public spheres... Additionally, they may also be societal or individual, coming in the form of racism, discrimination and distancing. Differences related to the immigrants' culture of origin or professed religion, racist perceptions and linguistic differences are such barriers that can curtail integration. Immigrants cannot successfully be inserted unless the host society is ready to accept their differences and receive their contributions. (pp. 38-39)

These barriers can impede the migrant's attempt to integrate into the new society, leading to unexpected depressive feelings contrary to what an individual expects from the receiving country, which consequently cause them to underestimate their origin.

A corresponding concept to understand acculturation in migration is the cultural identity. Cultural identity refers to the characteristics and knowledge of every individual including the totality of attitude, behaviors, history, place, nationality, gender, language, religious beliefs, and sexual orientation. D. Bhugra (2004), in "Migration, distress and cultural identity", posits that religious beliefs are important aspects that build the individual's cultural identity as they preserve one's values and give him/her a sense of belonging, anywhere, away from home (129). That is why losing the migrant's moral values or feeling guilty for deserting religious values are aspects that lead to "cultural bereavement" (Eisenbruch, 1991, p. 674). In the migration context, cultural identity is commonly formed by the migrants' cultural norms to which they 
belong and the new environment they become parts of. Thus, the contact between the migrant with the host society may lead to assimilation, rejection, integration or deculturation. In terms of rejection, Bhugra holds that the individual or the collective group to which he/she belongs withdraws from the larger society. With deculturation, the individual experiences a loss of cultural identity, alienation and acculturative stress that further add to the sense of failure, loss and poor self-esteem (2004, p. 133).

\section{Leila Aboulela}

Leila Aboulela, an acclaimed writer, was born in Cairo to a Sudanese father and an Egyptian mother in 1964. She grew up in Khartoum where, although she was a Muslim, she went to a Catholic school and the Khartoum American School, an education which inspired her with insights into other cultures and beliefs. She belongs to the Arab Anglophone writers who use English rather than Arabic to avoid "cultural restriction and censorship and to optimize exposure" (Nash, 2007 , p. 12). Her residence in Britain provides her with a subject matter that shapes an emerging awareness of the conflicts of migration and the difficulty of creating a sense of home in the new country of residence. Her literary publications are now widely recognized by Western critics and attract the interest of academics and researchers alike. As a migrant writer, her writings go beyond notions of diasporic lives and transnational experiences, standing between the culture of her homeland and that of the host country and "equipped with first-hand knowledge of both cultures" (Sarnou, 2014, p. 68). She has remarkably established a significant literary reputation, winning several awards and receiving critical praise from two of Africa's leading contemporary writers, Ben Okri and J.M. Coetzee.

Like most of her fellow Arab Anglophone writers, she engages her reader to themes, such as double-consciousness, hybridity, in-betweenness, transcultural singular experiences, as well as questions of stereotyping, ethnic representation, reception, and identity formation (Al Maleh, 2009, p. xi). She stresses the idea that hybridization in her lifestyle in Scotland is a way of inscribing her African

\section{Mistiqiya}

International Journal of African-Egyptian Studies

Vol.1 Issue 2 (2021) 
and Muslim identity in the mainstream culture of the British. This is clearly stated in Geoffrey Nash's words:

Aboulela's residence in Britain provided her with a subject matter: a terrain against which she could not only set her Sudanese heritage, but which she could employ to encapsulate a new identity: that of the Muslim Arab/African woman in exile (2007, p. 135).

\section{“The Museum" (1999)}

Moving to Aboulela's "The Museum" (1999), it was the winner of the first Caine Prize for African Writing in 2000. It was selected among fifteen short stories of diverse women writers in Africa to be published in the short story collection, Opening Spaces: An Anthology of Contemporary African Women's Writing (1999). Vera, the editor of this collection, states that Leila Aboulela:

welcomes the reader of "The Museum" with a controlled and confident exploration of a woman in exile as she ponders the dichotomies of arranged marriages, the transforming power of an overseas education, the imbalance of family ties, [and] the nature of love. (1999, p. 4)

Furthermore, it has become the central piece of the short-story collection in The Coloured Lights (2001). Later, it has been anthologized in Aboulela's story collection Elsewhere, Home (2018) by Telegram. According to Ileana Sora Dimitriu (2014), "[The Museum] is indeed the most complex story of all in that it offers a nuanced reflection on the trauma of dislocation, while at the same time, also suggesting a degree of relief through faith-based aspirations" (p.73). Recently, Arifa Akbar, in her review, "Elsewhere, Home by Leila Aboulela", claims that homesick immigrants and Islam are the main themes in Aboulela's stories (2018). Additionally, Porochista Khakpour, in his review "Stories of the Muslim Immigrant Experience, From a Sudanese Writer Now Living in Scotland" describes her use of realism in "The Museum" as a "vivid reflection

\section{Mistiqiya}


in a pond, as accurate as glass's gaze but rippled to capture life as a thing shivering and fluid even when seemingly still” (2019).

\section{Depiction of Alienation at Aberdeen University}

Shadia, the protagonist, is a Sudanese post graduate student, moves from her Arab African Islamic country, Khartoum, heading to Aberdeen in search of a better education. The story begins with a graphic portrayal of her disorientation which results from the strange appearance of her Scottish colleague with his "long, straight hair that tied up with a rubber band" and "his silver earrings". This different look, in Shadia's cultural lens, signifies "the strangeness of the West, another culture shock" (Aboulela, 2018, p. 157). It makes her feel afraid as she has never seen such a man. Moving to the early days of the term, Shadia is also confused by the "cold" and "grim" inhospitable university. She describes her perplexity as:

Someone tossed around by monstrous waves. Battered as she lost her way to the different lecture rooms...The course required a certain background, a background she didn't have...she and the other African students, the two Turkish girls and the men from Brunei. As this congregation from the Third World whispered anxieties in grim Scotland corridors... Us and them, she thought. (Aboulela, 2018, P. 158)

The above quotation signifies the migrant's loss of social role by becoming alienated in an unfriendly sociocultural environment. "Us" and "them", in the above quotation, stand for the opposing interaction between self-representation and social categorization, which establishes social alienation.

Likewise, Aboulela represents the confusion of other migrant students by pointing to a racism incident, recounted by Badr, Shadia's Malaysian friend, about being attacked in his house by racists, who damage his house window, just after Shadia informs the reader about the glossy University handbook for international students which implies that they are asked to be grateful, to accept the unfriendly treatment that is given to them and surrender to the vague and incomprehensible course system in Aberdeen university. Badr's story revisits

\section{Misriqiya}

International Journal of African-Egyptian Studies

Vol.1 Issue 2 (2021) 
Castro's view of racism and discrimination as critical barriers that disperse the migrant's expectations of a successful integration to the new culture of the host country.

Although this unfriendly environment makes Shadia feels out of place, she belongs to a kind of migrants known as "the bearers of hope", a term coined by C. Wagner to describe those who migrate seeking a better standard of living or fulfill their desires in obtaining a higher education. Certain features allied to this group, which include preparing for either opposition or integration into the host country (Wagner, 2016, p. 241). Thus, unlike her "Third World" colleagues who avoid interaction with the other, Shadia manages to get a better understanding of the Scottish society through her growing, cross-cultural relationship with Bryan, her Scottish male colleague, as he knows all the lectures and knows the system. Interestingly, the issue of an Arab female migrant's emotional relationship with a Western non-Muslim man is a repeated topic in Aboulela's work. Despite Shadia's sense of strangeness and alienation, she finds relief in beginning her friendship with Bryan, to cope with the new society hoping to gain social approval, praise, and admiration. Her attitude, at this point, recalls Berry's term "sociocultural integration" (2001).

Shadia, in her relationship with Bryan, tries to bridge the gap of communication between two different cultures to overcome her feelings of inferiority. Sometimes, Shadia achieves this by trying to be superior to Bryan. This is shown in a comparison, drawn by Shadia between the Nile in Khartoum and the river Dee in the host country when she says that the Nile is greater than the Dee. She tells Bryan that his Dee is nothing but a stream. Bryan, on the other side, doesn't exert effort to defend his river Dee. In another situation, when she expresses her dislike for Bryan's earrings, he immediately tugs them off. At this moment, she feels troubled as "he wasn't smiling". She fails to understand if he does so to please her or for another reason. One single time, he expresses his admiration to her walking style saying, "Ye walk like a princess' (Aboulela, 2018. P. 171). It is noticed that Shadia's overt offensiveness and snobbery towards Bryan and her inability to comprehend his feelings towards her dispossess any possibility of mutual understanding between east and west.

\section{Misriqiya}

International Journal of African-Egyptian Studies

Vol.1 Issue 2 (2021) 
Though Shadia's relationship with Bryan provides her with feelings of integration in her new place, it creates inside her a sense of guilt, which "was like a hard-boiled egg stuck in her chest" (Aboulela, 2018, p. 175). Entering the cafeteria hand in hand with Bryan is also deplored by some of Shadia's foreign colleagues who possess the same cultural identity. For example, one of her friends, the Turkish girl, "raised her perfect eyebrows" as a sign of condemnation, and her friend, Badr, "quickly looked away" (Aboulela, 2018, p.169) when his eyes and Shadia's met. Shadia's sense of guilt results from her respect and conformity to her Arab Islamic identity, considering any premarital relationship between men and women a sin, which damages the family's reputation and the teachings of Islam. Psychologically, this conflict inside her recalls the "acculturative stress" and "cultural bereavement" which results from the dissonance between one's culture of origin and the host culture.

\section{Invisibility of African Identity at the African Museum}

Museums are, by and large, supposed to keep and display cultural heritage, to transmit its real meaning. However, R. MacLeod, in "Postcolonialism and museum knowledge: revisiting the museums of the Pacific" describes museums as "embodiments of possession and power, part of whose business was setting boundaries-architectural and conceptual-imposing hierarchies and structuring meanings" (1998, p.313). In the same vein, Michael Baxandall asserts that it is impossible to display other cultures without putting a construction upon them (1991, p. 34). This notion is further explicated by WEB Du Bois' view that many migrant visitors face a dilemma and feelings of alienation when entering a national or international museum, where they are not figured. In this regard, the museum as represented in Aboulela's "The Museum”, exemplifies the western misrepresentation of Africa. Towards the end of the story, Shadia is invited by Bryan to visit an African museum in Aberdeen. In the African museum, she is stunned by the same negative feelings of rejection and inferiority she has on her 
first days at university. During their visit, Shadia and Bryan come across a statue of "a Scottish man from Victorian times..., [sitting] on a chair surrounded with possessions from Africa" (Aboulela, 2018. P. 176). Staring over the African artifacts, Shadia is unable to identify herself or her history with anything in this museum, for "[n]othing was of her, nothing belonged to her life at home, what she missed. Here was Europe's vision, the clichés about Africa: cold and old" (Aboulela, 2018. P. 177). In this sense, the African objects fail to speak with their voice; instead, they speak with the dominant voice in the host country. That is why the protagonist feels denigrated and outraged by the lies transmitted by the orientalist images of Africa.

The misleading role of the museum in shaping how the west perceives Africa reminds us of Edward Said's words about the East-West encounter. In his groundbreaking book, Orientalism (1978), Said demonstrates how the West has misrepresented the orient and how the east or the orient has been always represented not by themselves, but by the occident as a contrast to Europe. This is best described, by Said, as:

It is Europe that articulates the Orient; this articulation is the prerogative, not of a puppet master, but of a genuine creator, whose life-giving power represents, animates, constitutes the otherwise silent and dangerous space beyond familiar boundaries. (p. 57)

In a similar vein, John McLeod (2020) explains this opposition by saying that it:

[I]s not of equal partners. The orient is frequently described in a series of negative terms that serve to buttress a sense of the west's superiority and strength...thus...east and west are positioned through the construction of an unequal dichotomy. The west occupies a superior rank while the orient is its 'other' in a subservient position. (p. 41)

In this context, Aboulela problematizes Western museums revealing their Eurocentric prejudices against the West.

As a "bearer of hope", Shadia comes to this museum "expecting sunlight and photographs of the Nile, something to appease her homesickness, a comfort, a message. But the messages were not for her, not for anyone like her". Unlike 
the toxic exhibits detached from place and time, she asserts that she is "too modern, too full of mathematics" (Aboulela, 2018, p.178). It is noted that Bryan's preoccupation with what is written on the glass of the cabinet, "that strength" in his eyes, highlights his strong faith in those days, which adds to her sense of alienation. As a result, her relationship with Bryan comes to an end because, for her, his vision of Africa is a symbol of the European's image of her homeland, which denigrates her identity. One would see that the confusion here is that Bryan sees Shadia as an African from Sudan in the sense of being a Black African, whereas Shadia sees herself as an Arab in Africa. Revisiting Berry's concept of "deculturation", the protagonist's poor self-esteem, at this moment, is intensified, leading to feelings of worthlessness, hopelessness and helplessness, which are acute symptoms of depression. That is why when Bryan tries to discuss his Orientalist misconceptions with her, Shadia feels exhausted, too tired to challenge these misrepresentations. Hence, instead of getting them closer to each other, the visit to the museum produces a cultural gap between them, mystifies the protagonist's vision of her own cultural identity, and causes psychological injuries. Commenting on her helpless behavior towards rejection, the narrator says,

If she was strong she would have explained and not tired of explaining. She would have patiently taught him another language, letters curved like the epsilon and gamma he knew from mathematics. She would have showed him that words could be read from right to left. If she was not small in the museum, if she was really strong, she would have made his trip to Mecca real, not only in a book. (Aboulela, 2018, p. 182)

This was indeed the reason for the separation. Shadia, as an Arab woman from Sudan in Africa, failed to reveal her true identity to Bryan as an Arab but instead pretended to be an African. And having already presenting herself as an African to Bryan she should have expected nothing less order than Bryan's vision of her as an African in the right sense of the concept which Europeans understand. So in effect Shadia's identity alienation arose fundamentally from her false identity definition and from clash of cultures. This was further proven

\section{Mistiqiya}


by the absence of a picture of the River Nile - a symbol of life among the Arabs of Sudan and Egypt in the Museum.

\section{Conclusion}

Leila Aboulela's “The Museum" (1999), provides an authentic model of crosscultural encounter, highlighting two important issues: first, the "integration" strategy adopted by Shadia, the Sudanese female protagonist, as a way to cope with the new culture of the receiving land, second, the feelings of alienation resulting from the misleading European vision of the African culture exhibited in the western museum, which leads to a sense of "deculturation". The protagonist, as a representative of the Arab African migrant, is torn between her desire to assert her identity and accommodate herself to a new society that is unfriendly and indifferent. Analyzing the short story has provided us with a clear image of the hostile and unwelcoming host land, represented by behaviors of racism, discrimination, and misrepresentation of the migrants' "cultural identity" and its negative impact on the psyche of the newcomers leading to serious depressive symptoms, such as, feelings of alienation, guilt, and hopelessness. Thus, the migrant's daily life is signified as complex in which he/she is torn between the continual attempts to be part of the new culture while resisting exclusion and deprecation. Finally, through the depiction of Shadia's fateful visit to the Scottish museum, she removes the image of the museum from its basic setting as knowledge-based location to be a place spreading delusions and misrepresentations of ethnic identities.

\section{References}

Aboulela, Leila (1999). The Museum, in Elsewhere, Home (2018). Telegram Press.

Abrams, D., \& Hogg, M. A. (2006). Social identifications: A social psychology of intergroup relations and group processes. Routledge.

Akbar, Arifa (9 Jul 2018). Elsewhere, Home by Leila Aboulela - review. The Guardian. 
Al Maleh, L. (Ed.). (2009). Arab voices in diaspora: Critical perspectives on Anglophone Arab literature. BRILL.

Baxandall, M. (1991). Exhibiting intention: Some preconditions of the visual display of culturally purposeful objects. In Ivan Karp \& Steven D. Lavine (Eds), Exhibiting cultures: The poetics and politics of museum display, 33-4.

Berry, J. W. (2001). A psychology of immigration. Journal of social issues, $57(3), 615-631$.

----- (2003). Conceptual approaches to acculturation. American Psychological Association.

Bhugra, D. (2004). Migration, distress and cultural identity. British medical bulletin, 69(1), 129-141.

Dimitriu, I. Ş. (2014). Home in Exile in Leila Aboulela's Fiction. BAS British and American Studies, (20), 71-80.

Du Bois, W. E. B. (2008). The souls of black folk. Oxford University Press.

Eisenbruch, M. (1991). From post-traumatic stress disorder to cultural bereavement: Diagnosis of Southeast Asian refugees. Social Science \& Medicine, 33(6), 673-680.

Khakpour, Porochista. (March 11, 2019). Stories of the Muslim Immigrant Experience, From a Sudanese Writer Now Living in Scotland. New York Times

MacLeod, R. (1998). Postcolonialism and museum knowledge: revisiting the museums of the Pacific. Pacific Science, 52 (4), 308-3018.

McLeod, J. (2020). Beginning postcolonialism. Manchester University Press.

Nash, G. (2007). The Anglo-Arab encounter: Fiction and autobiography by Arab writers in English. Peter Lang.

Said, Edward. (1978). Orientalism. Pantheon Books.

Sangalang, C. C., Becerra, D., Mitchell, F. M., Lechuga-Peña, S., Lopez, K., \& Kim, I. (2019). Trauma, post-migration stress, and mental health: a comparative analysis of refugees and immigrants in the United States. Journal of immigrant and minority health, 21(5), 909-919.

\section{Nisriqiya}


Sardinha, J. (2009). Immigrant associations, integration and identity: Angolan, Brazilian and Eastern European communities in Portugal (p. 340). Amsterdam University Press.

Sarnou, D. (2014). Narratives of Arab anglophone women and the articulation of a major discourse in a minor literature. International Studies: Interdisciplinary Political and Cultural Journal (IS), 16(1), 65-81.

Vera. (1999). Opening spaces: an anthology of contemporary African women's writing. Heinemann.

Wagner, C. (2016). Migration and the Creation of Hybrid Identity: Chances and Challenges. In The Phenomenon of Migration (pp. 237-255). Scientia Moralitas Research Institute.

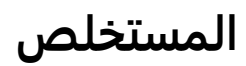

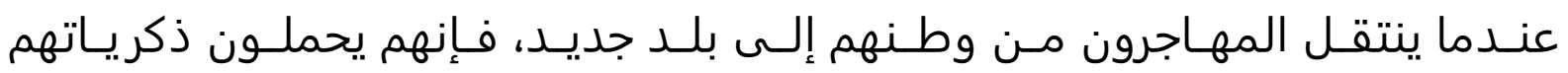

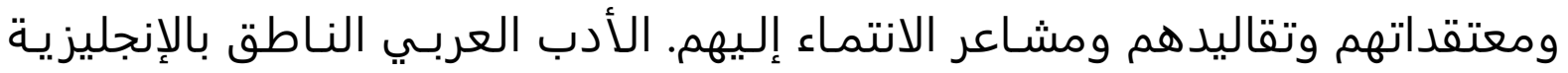

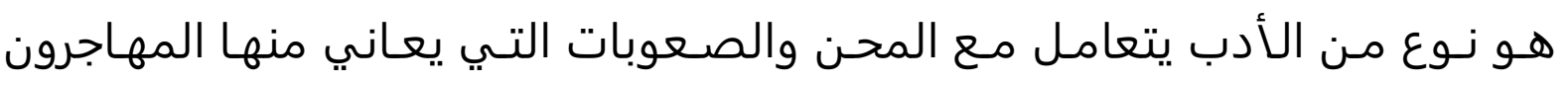

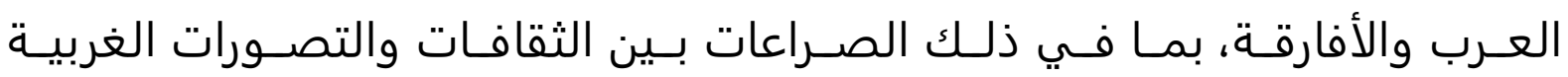

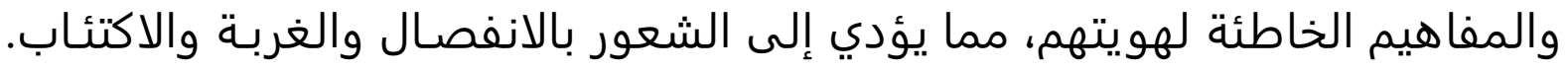

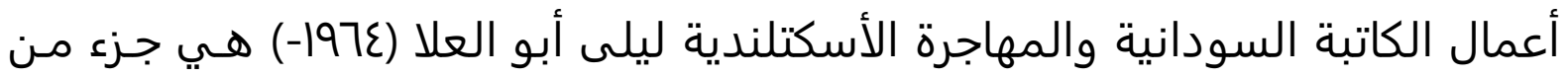

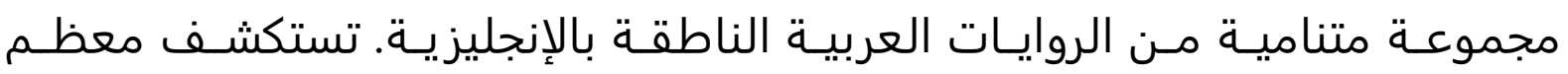

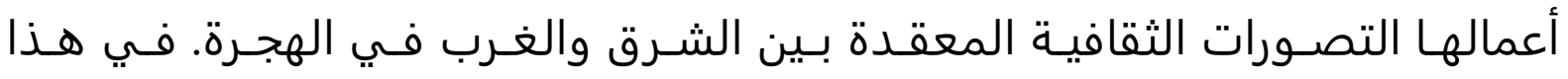

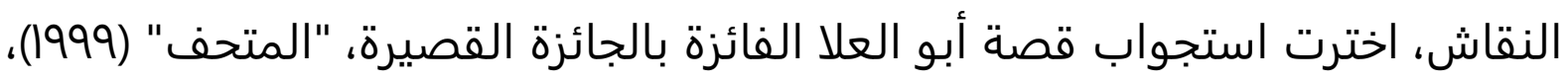

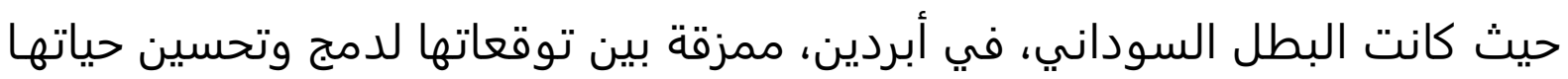

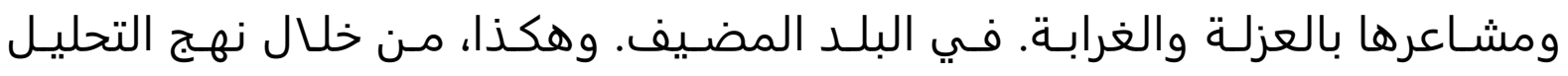

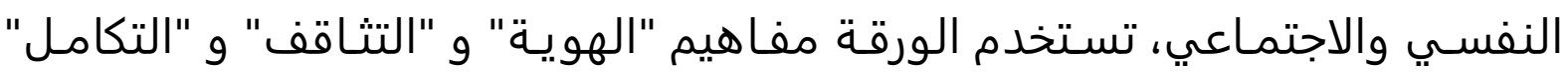

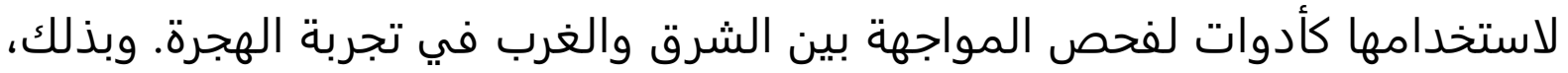

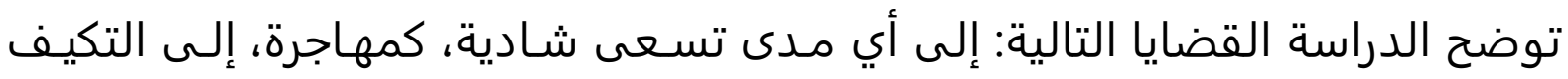

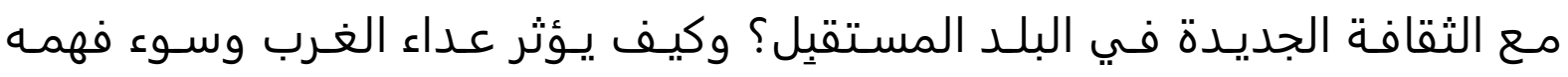
لهويتها الأفر يقية سلباً على سلامتها النفيدا لندسية؟

Misriqiya

International Journal of African-Egyptian Studies

Vol.1 Issue 2 (2021) 